\title{
深部ボアホール観測のための地殼活動総合観測装置および 地殼応力測定装置の開発と興味ある成果の例
}

\author{
名古屋大学大学院環境学研究科地震火山・防災研究センター* 山 内 常 生 \\ 財団法人地震予知総合研究振興会 東濃地震科学研究所** 石 井 紘 - 浅井 康 広 $\cdot$ 大久保慎人 \\ 東京大学地震研究所*** 松 本 滋夫 \\ 名古屋大学大学院環境学研究科地震火山・防災研究センター* 吾 妻 瞬 一†
}

\section{Development of Deep Borehole Instruments for Both Multi- Component Observation and in situ Stress Measurement, and Some Interesting Results Obtained}

\author{
Tsuneo YamauchI \\ Graduate School of Environmental Studies, Nagoya University, \\ Furo-cho, Chikusa-ku, Nagoya 464-8602, Japan \\ Hiroshi IsHII, Yasuhiro AsaI and Makoto ОкUво \\ Tono Research Institute of Earthquake Science, 1-63 Yamanouchi, \\ Akeyo-cho, Mizunami, Gifu Pref. 509-6132, Japan \\ Shigeo Matsumoto \\ Earthquake Research Institute, the University of Tokyo, 1-1-1 Yayoi, \\ Bunkyo-ku, Tokyo 113-0032, Japan

\section{Shun-ichi AzUmA ${ }^{\dagger}$} \\ Graduate School of Environmental Studies, Nagoya University, \\ Furo-cho, Chikusa-ku, Nagoya 464-8602, Japan \\ (Received April 1, 2004; Accepted January 4, 2005)
}

\begin{abstract}
We have developed multi-component borehole instruments for borehole stations deeper than $1000 \mathrm{~m}$. The instruments are composed of 7 strainmeter components (4 horizontal, 2 inclined, and 1 vertical), 2 tiltmeters, 3 seismometers, 4 magnetometers, and a high-resolution thermometer. The instruments are also equipped with new systems for data transmission and data monitoring, even during installation, and for determining the instrument direction at the bottom of the borehole. We have also developed an intelligent-type strainmeter based on the Ishii-type strainmeter for measuring in situ stresses. It is equipped with strain sensors, an A/D converter, a CPU, a memory, and a battery, and it has no outside cable. It is cemented into a deep borehole with expansion grout and then taken out by overcoring after it has coupled with the basement rock. By this procedure we can estimate in situ rock stresses. Observation in deep boreholes can avoid the problems of both artificial noise and
\end{abstract}

* ₹464-8602 名古屋市千種区不老町

** 干509-6132 瑞浪市明世町山野内 1-63

*** 个113-0032 東京都文京区弥生 1-1-1

†現所属：応用地質株式会社中部支社
干463-8541 名古屋市守山区瀬古東 2-907 Present address: Oyo Corporation, 2-907 Sekohigashi, Moriyama-ku, Nagoya 463-8541, Japan 
meteorological disturbance. It enables the performance of high $S / N$ ratio observations for detecting very small signals. The results obtained from deep borehole observations on the Izu Peninsula and in the Tono area of Gifu Prefecture have shown some interesting variations of strains and tilts related to the precursory phenomena of earthquakes. An example of in situ stress determination has also been demonstrated. In the case of deep borehole observation, we first measure the in situ stresses and then install a multi-component borehole instrument to monitor crustal activity. By this process we can continuously monitor stress variation. This kind of stress monitoring is very important in earthquake prediction research.

Key words: Multi-component borehole instrument, Cableless intelligent type strain meter, Monitoring of crustal activities, In situ stress measurement, Precursory phenomena of earthquake.

\section{§1.はじめに}

地表に近い観測地点における地殼変動記録は，気象の 影響, とりわけ，降雨の影響を受けやすい，このため， 高精度の観測でありながら $S / N$ 比が悪く，観測記録に 含まれる地震発生に関連した現象を見落とす可能性が高 い. 筆者らは，降雨による擾乱が小さい地下深部におい て地殼変動観測を行う目的でボアホール式の観測装置を 開発してきた．現時点では， $1000 \mathrm{~m}$ 以上の深度であっ ても地款変動連続観測が行える状況である.また，ボア ホール式歪計とデータロガーを一体にした初期応力測定 装置を開発してきた．この測定装置を使用すれば岩盤を 破壊することなく応力測定できる．最近は, 地殼応力を 測定した後, 同じ地点にボアホール式観測装置を設置 し, 地款に作用している応力状態を知った上で, 地款変
動を介して応力状態の変化を連続してモニターするよう にしている.

本報告では，ボアホール式地殼活動総合観測装置と初 期応力測定用のインテリジェント型歪計の構成, 測定装 置の埋設・設置方法，および使用方法の概要を成果とと あに報告する。

\section{§2. 地下深部における地殻変動観測の必要性}

降雨は複雑な過程を経て地下に浸透してタイムラグを 伴いながら地下水面に達し地下水面に擾乱を与える。 そ の後, 観測坑道近傍を河川の方向に流れ，擾乱を受けた 地下水面はゆっくりと元の状態に戻る. 降雨が地下に浸 透する過程, 浸透により乱された地下水面の変動, その 後に地下水面が回復する過程など, 岩盤中を移動する水

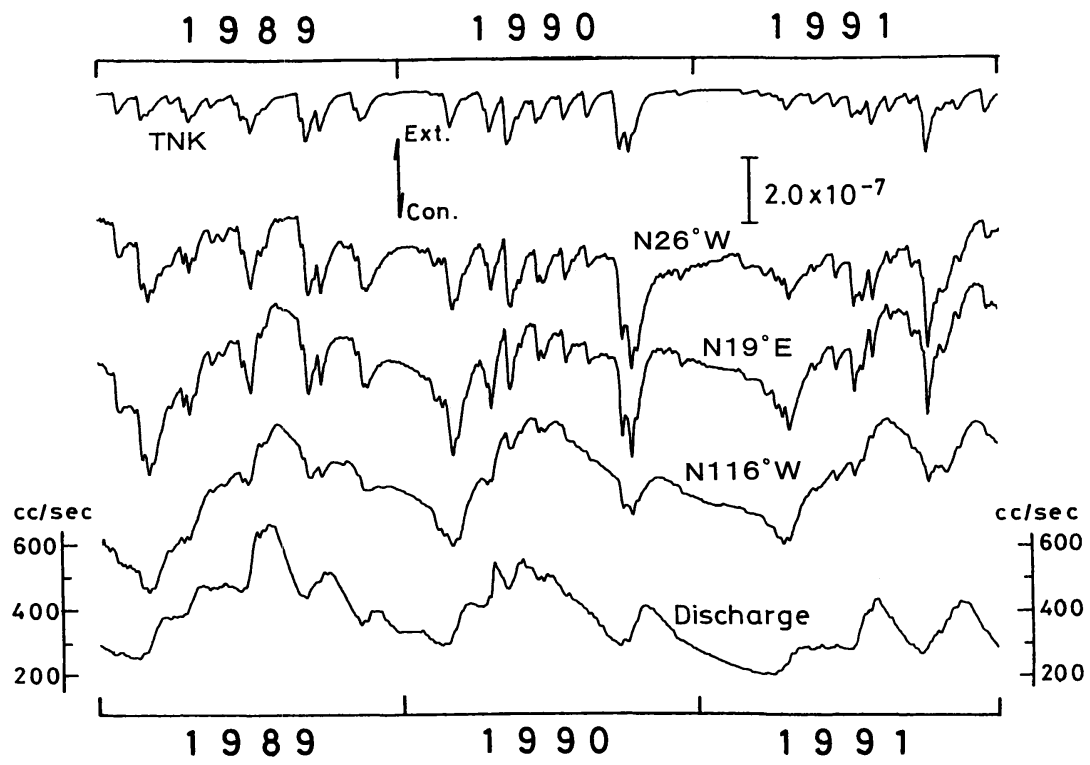

Fig. 1. Comparison of the discharge data with the strain data $\left(\mathrm{N} 26^{\circ} \mathrm{W}, \mathrm{N} 19^{\circ} \mathrm{E}, \mathrm{N} 119^{\circ} \mathrm{W}\right)$ observed by the silica-tube extensometers at Mikawa Crustal Movement Observatory operated by Nagoya University, Central Japan. Uppermost trace shows strain change predicted by a tank model simulation using precipitation data. 
の動きに対応して振幅や位相が異なる局所的な地壳変動 が生じる. その結果, 観測坑道に設置された伸縮計や傾 斜計が複雑な擾乱を受ける.

Fig. 1 に豊橋市の名古屋大学大学院環境学研究科の三 河地殻変動観測所における $40 \mathrm{~m}$ の伸縮計による 3 方向 の伸縮变化 $\left(\mathrm{N} 26^{\circ} \mathrm{W}, \mathrm{N} 19^{\circ} \mathrm{E}, \mathrm{N} 116^{\circ} \mathrm{W}\right)$ と坑道内湧水量 変化を示す. この図は, 伸縮変化と降雨量・地下水面の 変化との関係を示す典型的な例である. Fig. 1 から分か るように $\mathrm{N} 26^{\circ} \mathrm{W}$ 方向と $\mathrm{N} 19^{\circ} \mathrm{E}$ 方向に短周期変化が見 られる.この短周期の丕変化は降雨による影響であり, 降雨量を入力とする 3 段のタンクモデルにより予測す ることができる [山内・他 (1981)，山内 (1981)]. この タンクモデルによる予測值を Fig. 1 の上部に TNK とし て示した. 三河地殼変動観測所の場合, 降雨直後に収縮 しその後もとに復する短周期の地款変動は, 降雨が地下 に浸透する過程で生じる過渡的な歪変化であると推測し ている. また, Fig. 1 から分かるように, N19E 方向と, $\mathrm{N} 116^{\circ} \mathrm{W}$ 方向に年周変化が現れる.この年周変化は最 下部に示した湧水量変化とよく一致し, 湧水量が多い夏 期には伸張し，湧水量が少ない冬期には収縮する．この 湧水量変化むおおむね降雨量を入力とする別の 5 段の タンクモデルの出力で近似できる [Yamauchi (1993)]. 年周変化に代表される長周期の地殻変動は, 地下に浸透 した雨水による地下水面の変動に対応する丕変化である と推定している.

Fig. 1 で示したような表層で生じる局所的な地殸変動 は，観測地点が深くなれば減衰するはずである．瑞浪で 観測した深度の異なる地点における観測結果の比較か ら, 浅井・他 (2003) は, Fig. 2 のような結果を得てい る.この図には, 名古屋大学環境学研究科の瑞浪観測点 における歪記録（NAMZ：坑道を利用する長さ $30 \mathrm{~m}$ の 伸縮計 3 成分) 之, 坑道入り口にある東濃地震科学研究 所の戸狩観測点における歪記録（TGR350：深さ $350 \mathrm{~m}$ に設置したボアホール歪計 3 成分, 計器の直径は 10 $\mathrm{cm})$ が示されている. Fig. 2 から分かるように, 深さ 30 $\mathrm{m}$ 程度の地表付近に設置されている伸縮計の記録には 降雨の影響が認められるが, 深さ $350 \mathrm{~m}$ に設置されて いるボアホール歪計の記録には, 降雨の影響はほとんど 見られない. $S / N$ 比がよい地下深部であればわずかな異 常変動であっても検出できる可能性が高い.

\section{§3. ボアホール式観測装置}

ボアホール式の観測装置により地下深部で地殼変動連 続観測を行うためには, 多くの解決すべき問題がある. 大きく分類すれば,

1) ボーリング孔の掘削に関わること,
2）観測装置の開発に関わること,

3）観測装置の設置に関わること,

4) 観測装置設置後の連続観測に関わること, が挙げられる.

これらは相互に関連し, どの問題が解決できない場合 でも地下深部における地殼变動連続観測には支障がで る. ボーリング孔の掘削や観測装置の設置に関わること では，ボーリング孔が曲がっていると観測装置を孔底ま で降下させることができないし，観測装置を設置する際 のモルタルの硬さや厚さを決めるには, 設置場所の岩盤 の物性を十分調査する必要がある. 設置深度が深い場 合, 膨張セメント（以下モルタルと記す）が固まるまで の時間を遅らせ, 設置完了までの作業時間を長くする必 要がある. 一方, 設置場所が深くなるとボーリング孔の 周りの岩盤内の水圧が高くなり, 浅い場所に比較して地 下水が湧出しやすくなる. 設置場所において地下水が湧 水すると観測装置と岩盤とのカップリング状態が悪くな り，岩盤の変動を正確に観測できなくなる．しかし，モ ルタルが固まるまでカップリング状態は判断できず, カップリングが悪いと分かった時点ではモルタルが固 まっており観測装置を引き上げることはできない. した がって, 設置深度が深い場合は, 湧水がある場合に備え, 以下のようにすべきである.

1) ボーリング孔の孔底をモルタルで固め,

2) モルタルが固まった時点でモルタルをリボーリン グし,

3）回収したモルタルのコアを観察しコアに湧水の痕 跡がないことを確かめ,

\section{4) 観測装置を設置する.}

一方, 深いボーリング孔では孔ロからの作業で観測装 置の設置方位を決めることは困難である、筆者らは観測 装置に複数の磁気センサを取り付け, 地磁気の方向を直 接求めることで解決した. この磁気センサは, 設置方位 の測定に使用するだけでなく観測装置の設置後, 地磁気 の連続観測をするために使用する.

観測装置の開発に当たっては, 小型・高感度・低消費 電力を目標にしてきた. 孔径が大きな深いボアホール孔 の掘削は費用がかさむため, 孔径の小さなボーリング孔 に設置できるよう, 孔径の小さなボアホール式観測装置 にしなければならなかった，現時点では小型・軽量化に 成功し地下深部に設置しやすくなった. 小型であっても 地球潮汐力に対応する微少な地殻変動を観測する必要が あり，高感度でなければならない，高感度にするため， センサを改良して感度を上げっつ, 孔壁の変位をメカニ カルに拡大し, センサの変位量を大きくする方法 [Ishii et al. (2001b)] を用いている. また, 低周波帯域でノイズ 


\section{Comparison of Precipitation effect between NAMZ and TGR350}

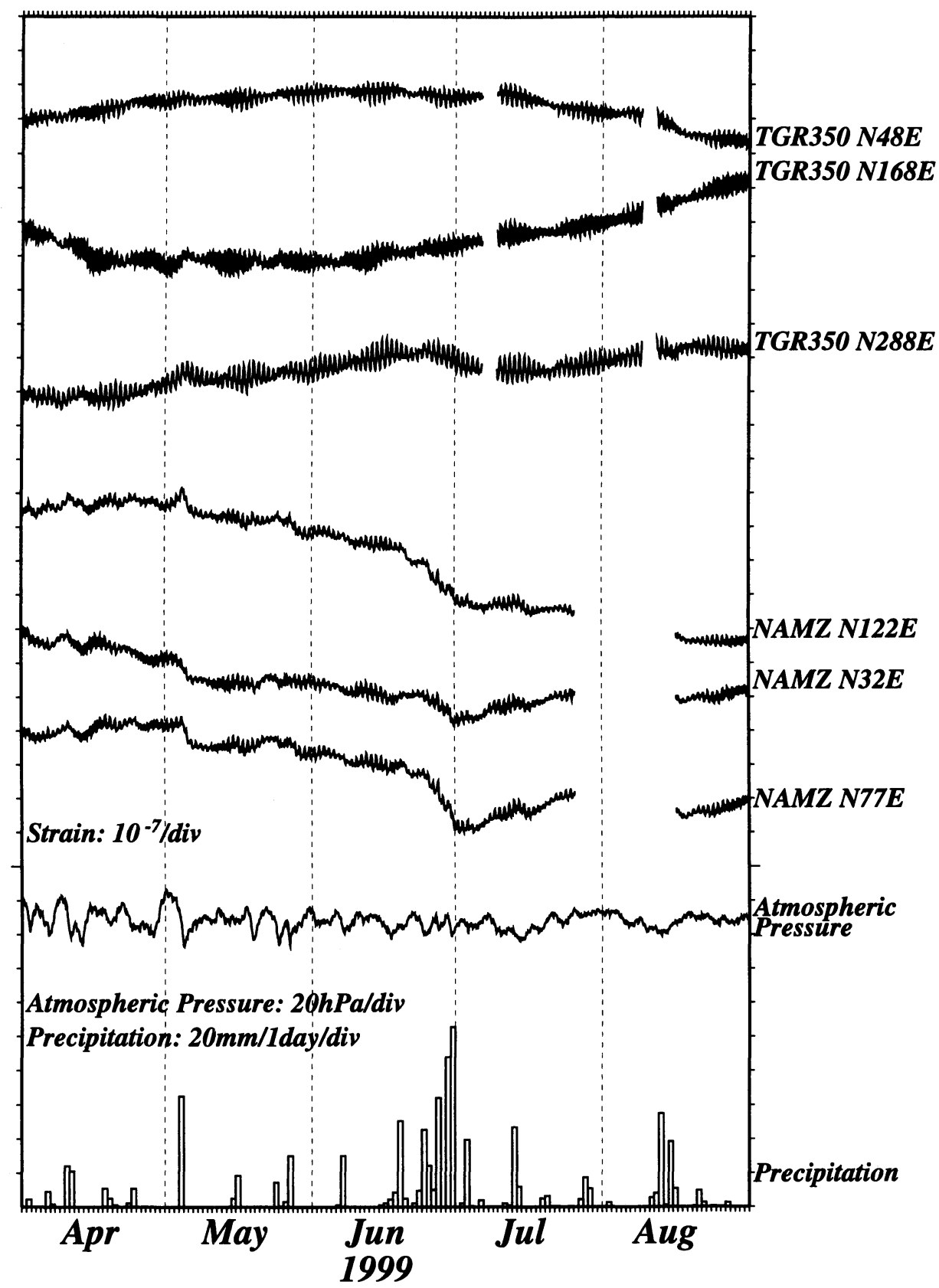

Fig. 2. Precipitation and crustal strain changes observed by the silica-tube extensometers in a shallow vault (NAMZ) and the strain meters in a deep borehole (TGR350, $350 \mathrm{~m}$ depth) constructed nearby NAMZ at Mizunami in the Tono area, Central Japan [Asai et al. (2003)].

が少なく，かつ，消費電力が少ないアンプを用いて信号 を増幅している.これらとともに, 複数の項目による地 殼活動総合観測が行えるよう, 多項目化之多成分化を
図ってきた。東濃地震科学研究所の屏風山観測点に設置 した観測装置の場合, 歪計 7 成分（水平 4 成分，斜め 2 成分, 垂直 1 成分), 傾斜計 2 成分, 短周期地震計 3 成 

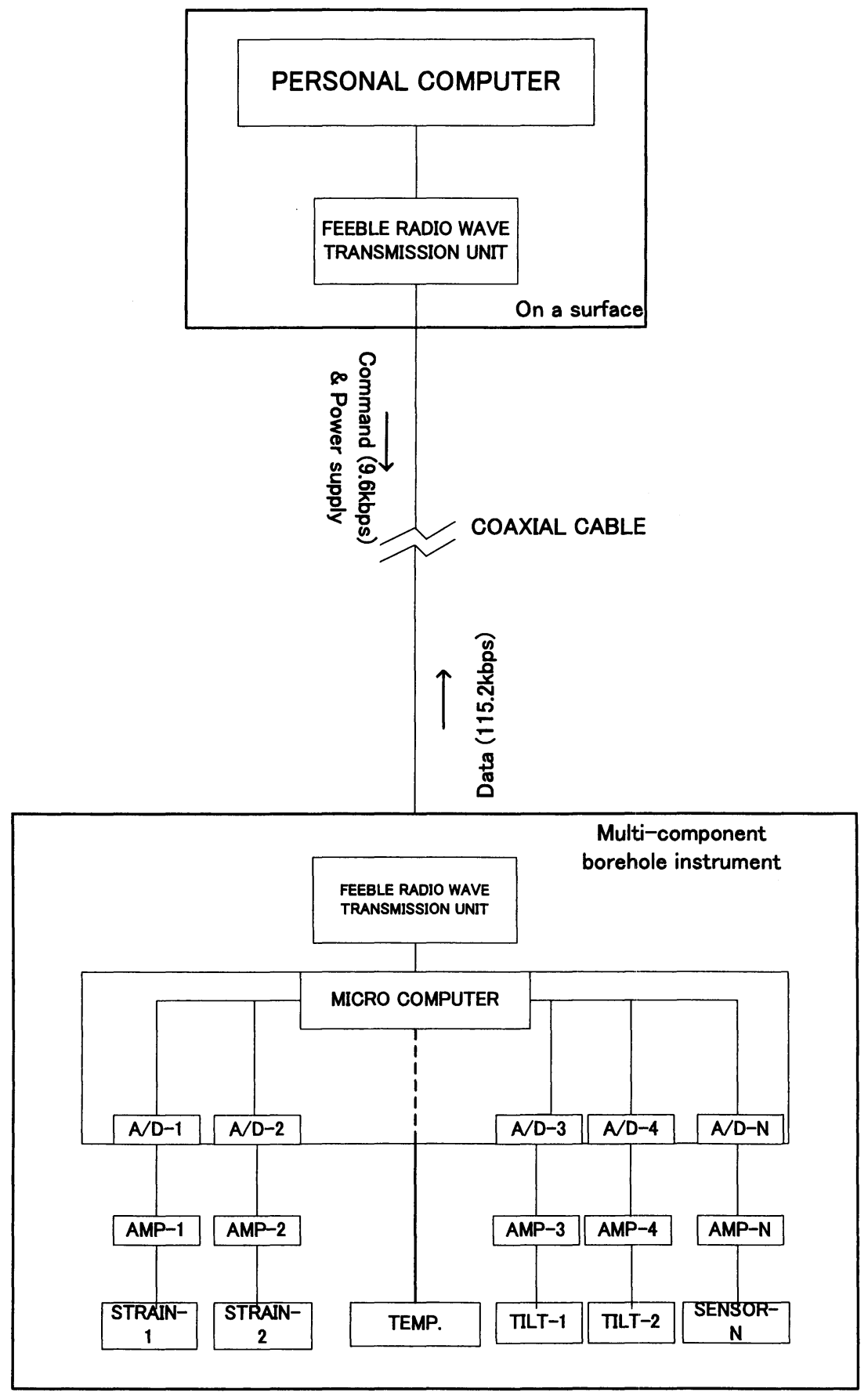

Fig. 3. Block diagram of interactive data communication system using a coaxial cable, which also supplies power for sensors.

分, 磁気方位計 4 成分（水平 3 成分, 垂直 1 成分）之, 高精度水晶温度計により構成されている. さらに，電源 線が長くなると電源電圧の降下が大きくなるため, 観測 装置の消費電力を可能な限り少なくするよう努力してき
た. 多成分の測定装置であるが, 現時点では, デー夕伝 送部も含めた消費電流は $\mathrm{DC} 12 \mathrm{~V}$ で $300 \mathrm{~mA}$ 程度であ る.

ボアホール式地殼活動総合観測装置は, モルタルで 
ボーリング孔の孔底に固定するため, 故障しても引き上 げることができない，このため，落雷に伴う誘導電圧か ら観測装置内部の電子回路を保護する必要がある，電子 回路を保護するには，第 1 に，落雷に伴う誘導電圧が電 源線を介して孔底の観測装置に進入することを避けるこ とであり，観測装置には，商用電源から直接電源を供給 せず,バッテリーを用いて電源を供給している.そして, 孔底の観測装置に給電する電源線にアレスターやッェ ナーダイオードを取り付け, バッテリーからの電源線に 過大な電圧が加わった場合，その電圧をアースラインに 流すようにしている．第 2 は，各センサの信号線から過 大な電圧が進入することを避けることであり，センサの 信号線に保護回路を取り付ける. 初期の頃は, 保護回路 をセンサごとに取り付けていたが，現時点では，孔底で デジタル信号に変換し時分割でデジタル伝送する方法に 変更しセンサからのアナログ信号線をなくした，そし て, デジタル伝送用の信号線にのみ保護回路を付けてい る，具体的には，デジタル信号を，1）光ファイバーを介 して伝送する方法と，2) 微弱電波をコイル結合させ同 軸ケーブルを介して伝送する方法を用いている.

ここでは，同軸ケーブルでデー夕伝送を行う方法につ いて述べる．孔底と孔口を同軸ケーブル（5D2V 相当） で接続し，両端に微弱電波を利用する無線送受信ユニッ 卜を取り付け，双方向通信をする，具体的には，同軸 ケーブルで観測装置に電源を供給しつつ, A/D 变換用 の同期信号を観測装置に伝送するとともに，デジタル化
したデータを観測装置から孔口まで伝送する。この方式 の開発により，従来まで使用してきた多芯で太く重量の あるアナログ信号線之電源線を省略することができ，地 下深部に観測装置が設置できる条件が整った．開発した 微弱電波を利用する双方向通信ユニットは, $60 \mathrm{~mW}$ 程 度の消費電力でありながら, 孔口から孔底へは $9.6 \mathrm{kbps}$ で, 孔底から孔口へはその 12 倍の $115.2 \mathrm{kbps}$ でデー夕 を伝送できる．現時点では，観測装置の消費電流は 300 $\mathrm{mA}$ 程度である. 現在使用している同軸ケーブルの 1 $\mathrm{km}$ 当たりの線抵抗は往復で 20 オーム程度であるため, 同軸ケーブルによる電圧降下を数 V に抑えることがで きる. 設置深度が $2 \mathrm{~km}$ であっても孔口では $24 \mathrm{~V}$ の直 流電源で対応することができる.

Fig. 3 に東濃地震科学研究所の屏風山観測点で実施し ている, 同軸ケーブルを用い電源の供給を行いつつデー 夕の双方向通信をする観測システムのブロック図を示 す。屏風山の場合, 地表からの深さ $1000 \mathrm{~m}$ の地点で GPS 信号に同期した高速サンプリングの地殸変動デー 夕が得られるようになった. A/D 変換データのサンプ リングは $10 \mathrm{~Hz}$ から $200 \mathrm{~Hz}$ で, 22 ビットの分解能で ある，将来は，ボアホール観測装置内の CPU のプログ ラムを地表から変更できるようにするとともに, 各セン サを小型の CPU で制御する方式に変更し，センサごと に個別の制御ができるようにしたい，さらに，通信回線 を利用することで, 研究室の CPU から各センサをダイ レクト制御したい。

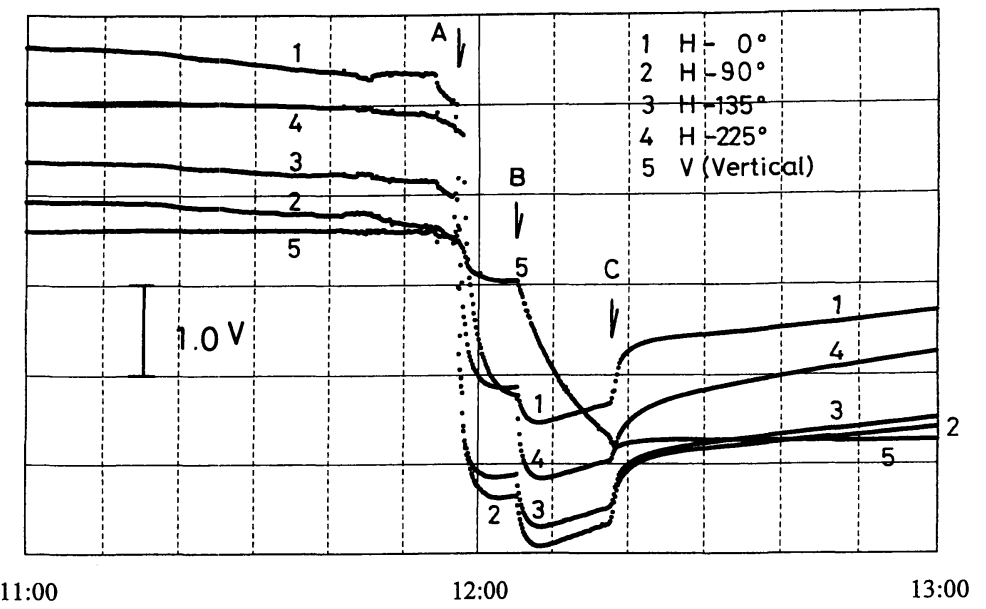

JUL.13 (2002)

Fig. 4. Strain changes in several 3-D directions observed by the multi-component borehole instrument during installation into a deep borehole at Takayama station, Central Japan. A: the instrument immerses in water near surface of borehole and stops until temperature of the instrument becomes stable. B: the instrument starts moving down into borehole bottom. C: the instrument plunges into grout at the bottom. 
Fig. 4 は名古屋大学環境学研究科の高山地震観測所に おいて観測施設を移転した際に得られた, ボアホール地 殻活動総合観測装置を設置したときのリアルタイムモニ タ一記録である. 水平 4 成分と垂直成分の歪記録が図示 してある. 図の A 点以前は孔口に観測装置を移動させ ているときであり移動に伴う乱れが記録されている，移 動後, 孔底にモルタルを入れ, その後, ボーリング孔を 水で満たす。その水を満たしたボーリング孔に挿入した 時間が $\mathrm{A}$ 点で, 観測装置の温度が安定するのを待ち, B 点で降下を開始した．降下した観測装置は C 点で孔底の モルタルに入り, その後は停止したまま, モルタルが硬 化するのをモニターした．水平成分と垂直成分ではメ力 二カルな部分の構造が違い, 温度变化に対する応答が異 なるため，ボーリング孔中を降下するときや，モルタル が硬化するときの変化が違っている.

高山の場合は, デジタルデータを光ファイバーで伝送 したが，無線ユニットによる伝送の場合は，電波でデジ タルデータを伝送できるため, 回転するドラムから簡単 にデータを取り出せる．地下深部に観測装置を設置する 場合, 予期せ女障害が発生する可能性があり, 不慮の事 態に対応するためにはリアルタイムで観測装置のデータ を取り出し，そのデータを監視しながら設置作業を進め ることが重要である.

同軸ケーブルでは観測装置を吊り下げることができな いため, 同軸ケーブルの補強を兼ねて金属製のワイヤー で覆う必要がある. 屏風山で採用したこの方式では, 観 測装置を設置する際, 観測装置と長い補強ケーブルを巻 いたドラムを一体として扱わなければならないため, 作 業性が悪い. 将来は，ケーブルの補強をカーボンロッド やグラスファイバーなどで行う方式に変更し, 荷重に耐 えるためのロッドの機能をもつ信号ケーブルを開発した い.この信号線内蔵ロッドであればコネクターで接続し つつボーリング孔に観測装置を降下させることができ, 測定装置を設置しやすくなる.

\section{§4. 初期応力測定装置}

地款に作用している応力が破壊強度を超えなければ地 震は発生しない, 地震発生を予測するためには, 地下深 部に作用している応力の值を知ることが最も重要であ る.しかしながら, 地下深部で応力を測定することは容 易ではない.

筆者らは，ボアホール観測装置を開発する過程で， メーカーの協力を得て, 低消費電力で作動する高感度の 変位センサを開発した，同時に，前記したようにセンサ の出力信号を孔底でデジタル化する方法を模索してき た.また，野外における地款変動観測を行うことを目的
にして低消費電力で作動するデータロガーの開発を進め てきた. これらの技術を統合することで, 歪計とデー夕 ロガーが一体となった, 信号線や電源線がない初期応力 測定用のインテリジェント型歪計を開発した［山内・他 (2000)].

この初期応力測定装置では, 以下のようにして原位置 の応力を測定する.

1) ボーリング孔の孔底に，小口径のボーリング孔を 掘削する.

2) 応力測定装置をボーリング孔の孔底にモルタルを 用いて設置する.

3) モルタルが固まり測定装置と孔底の岩盤との間が カップリングするのを待つ.

4) カップリング後に，測定装置を周囲の岩盤ととも にコアとして回収する.

5) データロガーのデータを取り出し, 逆解析から原 位置の応力値を求める.

モルタルが固まった後, 測定装置の周りの岩盤を, よ り孔径が大きなコアバーレルで掘削すれば, 岩盤から作 用している応力が解放され, 測定装置を含むコアには水 圧しか作用しなくなる，さらに，この測定装置を含むコ アを地表に引き上げれば，水圧も含め応力が解放された 状態の変形量が観測される．応力測定に関するシステム や工程に関しては松本・他 (2000), 松本・他 (2001) に 述べられている．筆者らが使用している初期応力測定装 置の特徴は, 測定装置の設置からオーバーコアリングを 完了し感度検定を終えるまで，あらかじめプログラムし たサンプリング間隔で岩石のコア内部でコアの変形量を 測定できることである.

Fig. 5 は岐阜県恵那郡福岡町で行ったオーバーコアリ ング前後の記録の例である. 福岡町では水平 3 成分と垂 直 1 成分のインテリジェント型歪計を使用した. 従来実 施されてきたオーバーコアリングの方法は, 設置した計 器の周辺のオーバーコアリングを連続して行う方法であ る. 筆者らは, インテリジェント型歪計の上部にある歪 計から徐々に, 丕計毎に時間差を設けてオーバーコアリ ングを行う。このため，オーバーコアリングを開始した 10 時 30 分頃から記録の乱れとステップ状変化が $\mathrm{N}$ $164^{\circ} \mathrm{W}, \mathrm{N} 76^{\circ} \mathrm{W}, \mathrm{N} 44^{\circ} \mathrm{E}$ 方向, さらに, 垂直方向成分の 順に生じている. 12 時 30 分頃インテリジェント型歪計 を岩盤から切り離し, そのまま孔底に静止させ歪計の出 力が安定するのを待った. 14 時 30 分頃から段階的にイ ンテリジェント型歪計を水で満たしたボーリング孔中か ら引き上げた. ボーリング孔中の温度変化の影響により 分かりにくいが, 引き上げる段階に見られるステップ状 の変化が水深の変化に対応した歪変化である. 福岡町に 


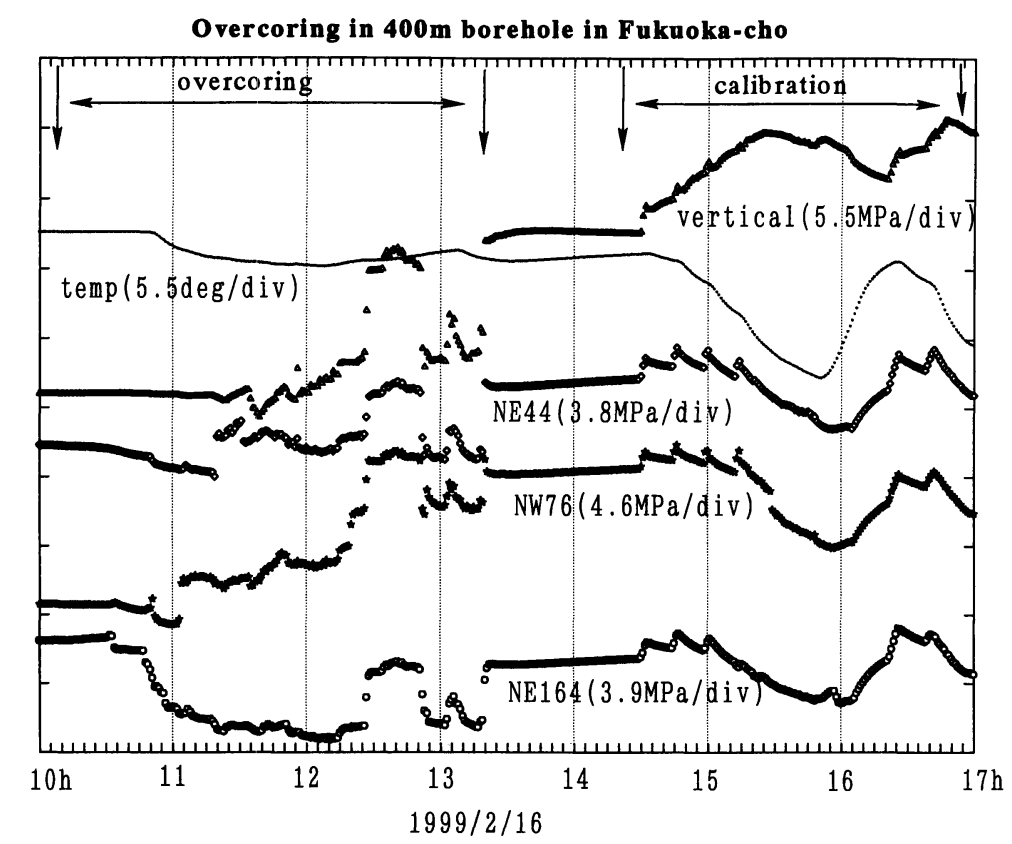

Fig. 5. Strain and temperature changes measured by cableless intelligent type strainmeter during overcoring in Fukuoka-cho $400 \mathrm{~m}$ borehole, Gifu prefecture, Central Japan.

おける初期応力測定の場合は，このときの水深に対する 丕変化を用い, 温度補正を行って感度検定值とした。こ こでは結果を示してないが，通常の場合，オーバーコア リングを行う前の歪と,オーバーコアリング後に孔底に 静止させた時の各成分の歪の差を利用し（水圧の差およ び温度変化の補正を行う), インバージョンにより初期 応力の大きさと方向を求める. この報告では, 垂直の ボーリング孔を利用して得られた水平成分のデータを解 析した. したがって, インバージョンを行う場合, 初期 応力の方向は水平であると仮定する. 解析方法に関して は, Mukai et al. (2004) を参照されたい. 筆者らは歪計 ごとに時間差を設けて各方向における応力解放を行い, そのときの歪変化を記録し， 3 次元的な応力值の情報を 得ようとしている, しかしながら, 現時点ではその解析 方法は確立していない，この方法が確立した時点で, 福 岡町のデータを再解析し, 初期応力の 3 次元的な情報を 引き出せるようにしたいと考えている.

オーバーコアリング開始前に, 孔底で周りの岩盤から 受けていた応力状態における歪変化と, コアとして地表 に引き上げられ応力解放された状態の歪変化を比較すれ ば, オーバーコアリング前後の応力解放に対応する歪変 化が分かる. 実際には, 測定装置の周りにはモルタルと 岩盤が同心円に近い状態で密着しているため, 感度検定 を行い，モルタルの影響を取り除く必要がある。筆者ら はオーバーコアリングにより得た, 歪計を内部に含むコ
アを水圧容器に入れ, 加圧してその加圧による歪変化か ら感度検定值を得るが, この感度検定作業をボーリング の作業現場で行うと, 環境温度の変化により加圧する圧 力が乱され解析しにくくなる。このため, 環境温度がほ とんど変化しない最寄りの地殼変動観測点の観測坑道等 を感度検定作業に利用する. Fig. 6 がその例で岐阜県吉 城郡神岡町の茂住坑道で行った感度検定時の記録であ る.はじめに加圧して大きく収縮させる，時間をおいて 徐々に減圧し, その後, 徐々に再加圧する方法をとる. 14 時 30 分頃に加圧を完了し減圧後, 15 時 15 分頃に再 加圧を開始した。この図から分かるように感度検定作業 を環境温度が安定している場所で行えば, データの乱れ が少なく, 精度の高い感度検定結果が得られる.

実際の解析は, 既知の静水圧に対する歪変化の大きさ と岩盤から受ける応力に対する歪変化の大きさが比例す ると仮定し, オーバーコアリングの前後の歪变化から, 温度補正を行ってそれぞれの歪計ごとに岩盤から受けて いた応力解放に伴って生じた歪変化を求める. その歪変 化から, 初期応力の方向が水平であると仮定し, イン バージョンで初期応力の方向と大きさを求める. この場 合, オーバーコアリング時にはインテリジェント型歪計 とコアとしての岩盤は同軸であり偏芯がないもとして解 析する.

Fig. 7 には和歌山県新宮市で行った初期応力測定の結 果を, 池田・他 (2001)により得られた水圧破砕法によ 
Calibration of sensitivity of cable-less strain meter

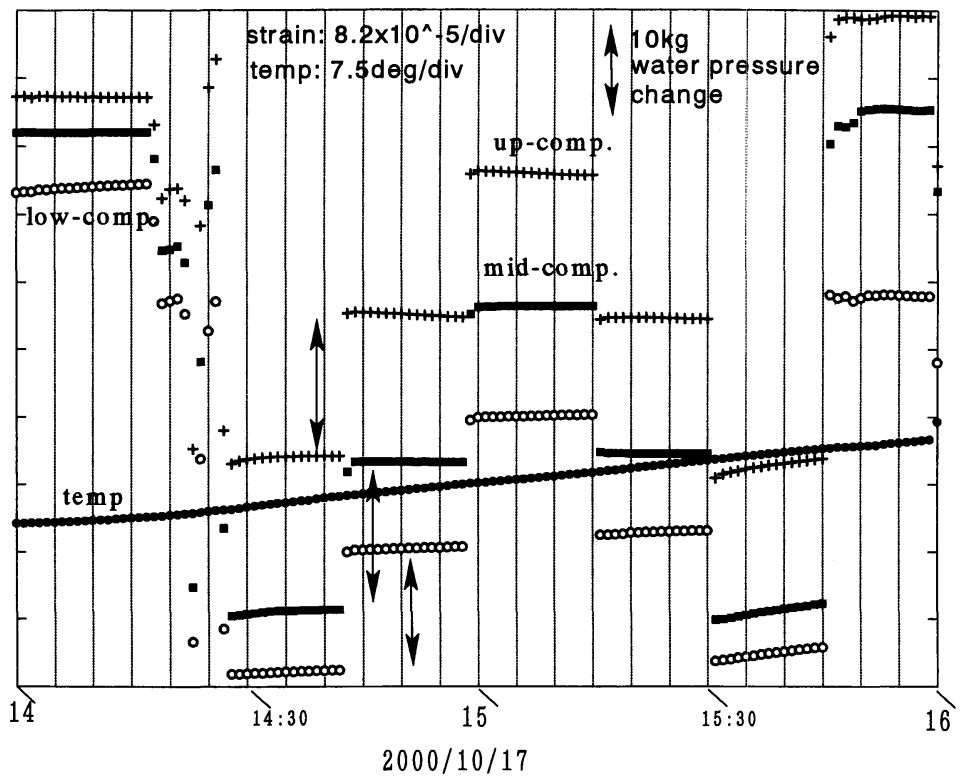

Fig. 6. Strain and temperature changes recorded by cableless intelligent type strainmeter during calibration of its sensitivity just after overcoring in the Mozumi Mine, Central Japan.

る初期応力の測定結果を示す図に加筆した．筆者らが得 た結果は大きな黒丸と白丸である. 大きさ，方向とも水 圧破砕法による結果とよく一致する，新宮の場合も，応 力解放前後の歪変化と水深に対する歪計の応答特性か ら，インバージョンで初期応力值と方向を求めた. 丕計 が岩盤と比較して十分硬いため，今回の加圧検定で十分 な結果が得られていると考えている. 我々のシステムの 場合は数値実験によれば偏芯の影響は最大で 10 パーセ ント程度であるが新宮の場合はほとんど同芯のコアが得 られている．詳しくは稿を改めて応力測定を中心にした 論文で議論する予定である.

\section{§ 5. 地震発生前後に観測された異常な地殼変動}

地震発生の場所を予測するためには, 地震発生に関連 した前兆的現象の観測事例を増やすことが基本である. ボアホール式の観測装置で観測した地震発生に関連した 前兆的地殻変動の例を Fig. 8 および, Fig. 9 に示す.

Fig. 8 left と Fig. 8 right は, 東京大学地震研究所の 伊東観測点で観測した, 1996 年, 1997 年, および 1998 年の伊豆半島東方沖の群発地震に関連した傾斜変化 (Fig. 8 left) と最大主歪の変化 (Fig. 8 right) である [石 井・他 (1998), 石井 - 他 (2001a), Ishii et al. (2001b)]. 群発地震の始まる前から通常之異なる傾斜変化や歪変化 が観測され, 群発地震の活動に呼応して, 傾斜ベクトル や最大主歪方向が加速的に変化した. そして, 傾斜べク
トルと最大主歪の方向が時期を合わせて北東一南西方向 に変化した直後に, 群発地震の中で最大の地震が発生し た. Okada et al. (2000) は上記の 3 個の伊豆の群発地震 以外の群発地震についてもデー夕を示し比較的大きな群 発地震の前には傾斜の前兆的異常変動が伴うことを示し た.このように異なる時期の群発地震すべてに同様の変 化が記録されたのは注目すべき事実である.

核燃料サイクル開発機構の東濃鉱山近傍では, Fig. 9a 〜 $9 \mathrm{c}$ で示すような別の事例が観測された［核燃料サイ クル開発機構 (2000), King et al. (2000)]. 観測点直下の 震源距離 $53 \mathrm{~km}$ 地点で発生した $M=3.9$ の地震に先行 して, SN-1 号観測井の地下水位が異常な上昇を示す (Fig. 9c) とともに，近接した 97FT-01 号孔のボアホー ル地殻活動総合観測装置の歪計で異常な最大せん断歪が 観測された (Fig. 9a). このときの歪み主軸の変化の詳細 をFig. 9bに示した. 地震発生の数日前から主歪に異常 が見られる. Fig. 9c から分かるように, SN-1 号観測井 には 97FT-01 号孔に地壳活動総合観測装置が設置され た以前の時期にも，地震の発生に先行し，1999 年 8 月 の例と同じパターンを示す地下水位の異常な上昇が観測 された.この事実は, 同様な現象が複数回発生したこと を示唆している. ただし, 本論文では図示しないが, SN1 号観測井に近接して SN-3 号観測井があり水位変化の 連続観測をしている。 しかし， SN-3 号観測井の水位変 化を見る限り地震発生と共にステップ状に変化し, SN- 


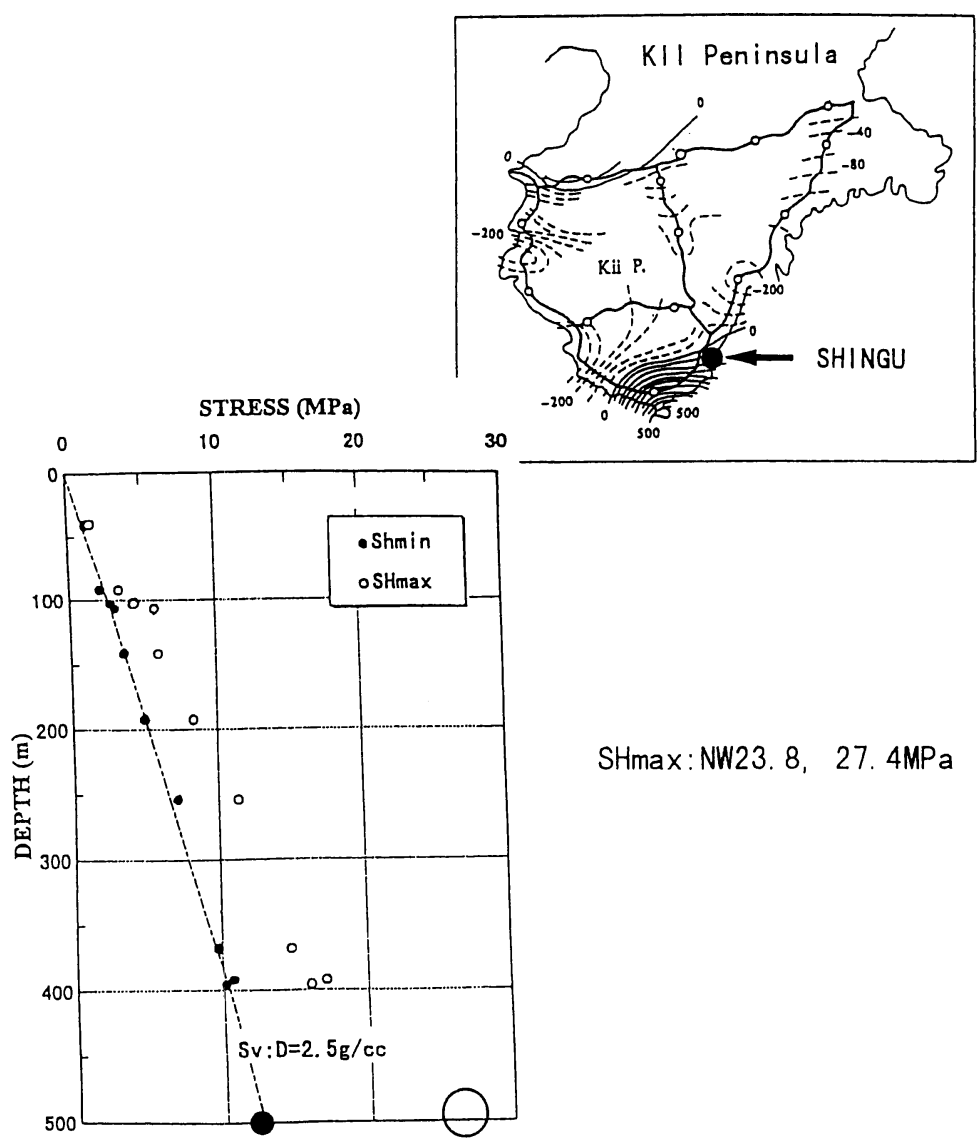

Fig. 7 Top. Location of Shingu drilling site with vertical deformation field in Kii peninsula after the 1944 Tonankai and the 1946 Nankaido earthquakes [Miyabe (1955)].

Bottom. Profile of the stress magnitude measured by hydro-fracturing method at various depths of Shingu station. Dashed line indicates the lithostatic pressure calculated from the density log data [Ikeda et al. (2001)]. Our result obtained by overcoring method is plotted at $500 \mathrm{~m}$ depth.

1 号観測井のように地震発生の前に上昇することはな い.この現象は, 地下水流動現象の複雑さを反映してお り, SN-1 号観測井は異常な地下水位変動が生じる条件 を備えている. 言い換えれば，せん断歪が加わると SN1 号観測井の帯水層には異常な圧縮力が作用し, 帯水層 中の間隙水圧が上昇する構造になっていると推測され る. いずれにしても, 地下深部の $S / N$ 比がよい地殻変動 観測点近傍で地震が発生すれば, これらの例のような前 兆的地殼変動が観測できるはずである.

東濃鉱山近傍の観測例では, 地震の発生に先行して最 大せん断歪が地球潮汐による変化より大きな異常を示し たにもかかわらず面積歪には異常が見られない，面積歪 に異常が生じていたとしても，潮汐変化よりかなり小さ い変化である. 仮に, 97FT-01 号孔に 1 成分の体積歪計 か設置されていたとしても，面積変化を伴わなかったこ とから, 異常現象は検知できなかったはずである. 気象
庁は東海地震の監視に主として体積歪計を用いている が, 情報量が多い多成分構成の観測装置を地壳活動の監 視にもっと役立てるべきであろう.

\section{§6. まと め}

筆者らは, 降雨の影響がない地下深部で地款変動や微 小地震の観測を行う目的で, 地殻活動総合観測装置を開 発し，段階的に設置深度を深くしてきた。観測装置の開 発過程で,

1) 伊豆東方沖の群発地震に先行する傾斜や最大主歪 の異常変化を 3 回の群発地震すべてにおいて観測した.

2) 面積歪がなくせん断歪が卓越する地震の前兆的変 化を観測した.

これらの事実から,「イベントの発生している領域に 十分近いところでノイズの少ない深部ボアホール観測を 実施すれば, 地震発生に関連した微少な地款変動が十分 


\section{Time variation of}

Descending tilt

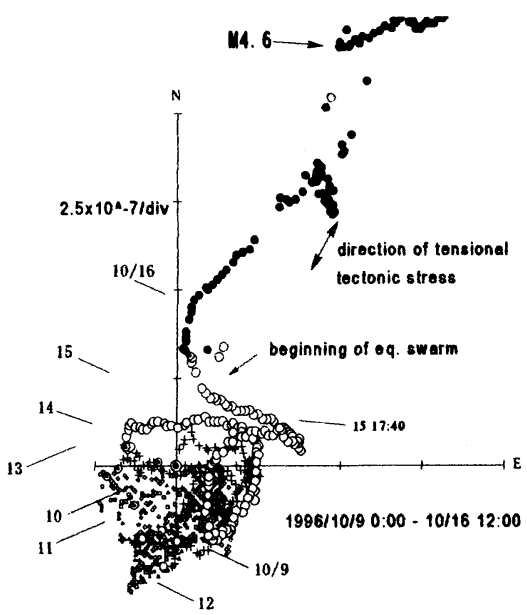

Time variation of Maximum principal strain

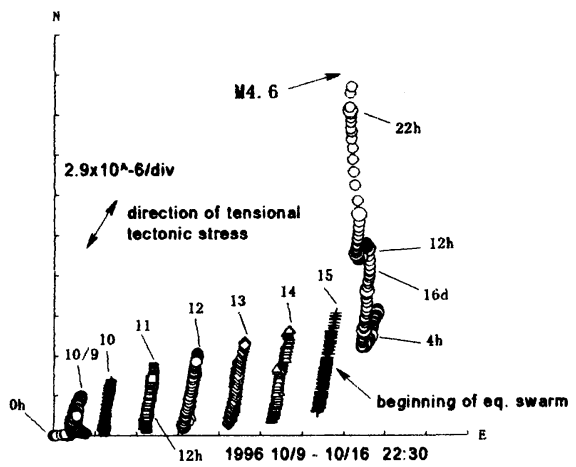

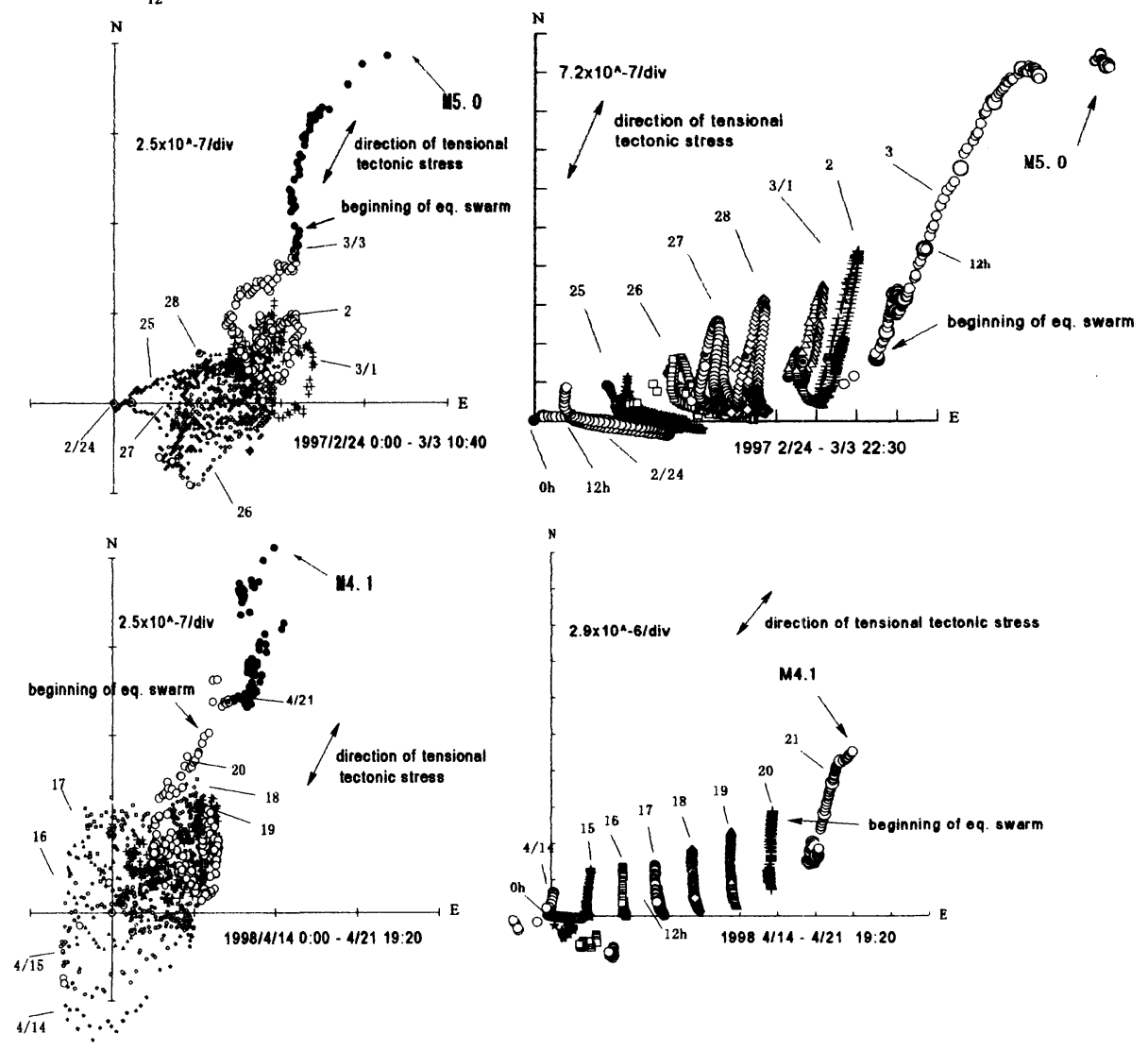

Fig. 8 Left. Time variation of vector diagrams of descending tilt direction obtained from tiltmeters of multi-component borehole instrument at Ito station in Izu peninsula, Japan. The data before and during three earthquake swarms of 1996, 1997 and 1998 are plotted. [Ishii et al. (2001a)].

Right. Daily change of maximum principal strain (tensional strain) from strainmeters of multi-component borehole instrument at Ito station in Izu peninsula, Japan. The data before and during three earthquake swarms of 1996, 1997 and 1998 are plotted. The data of each day are plotted by shifting in order to clarify the variation [Ishii et al. (2001a)]. 


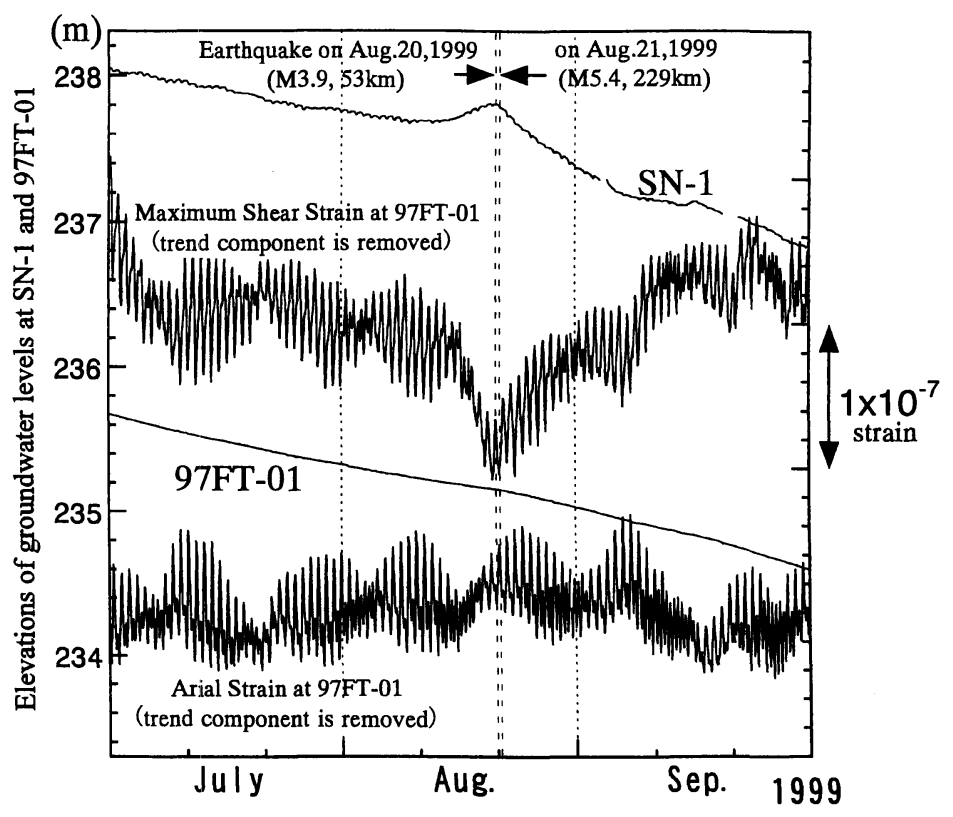

Fig. 9a

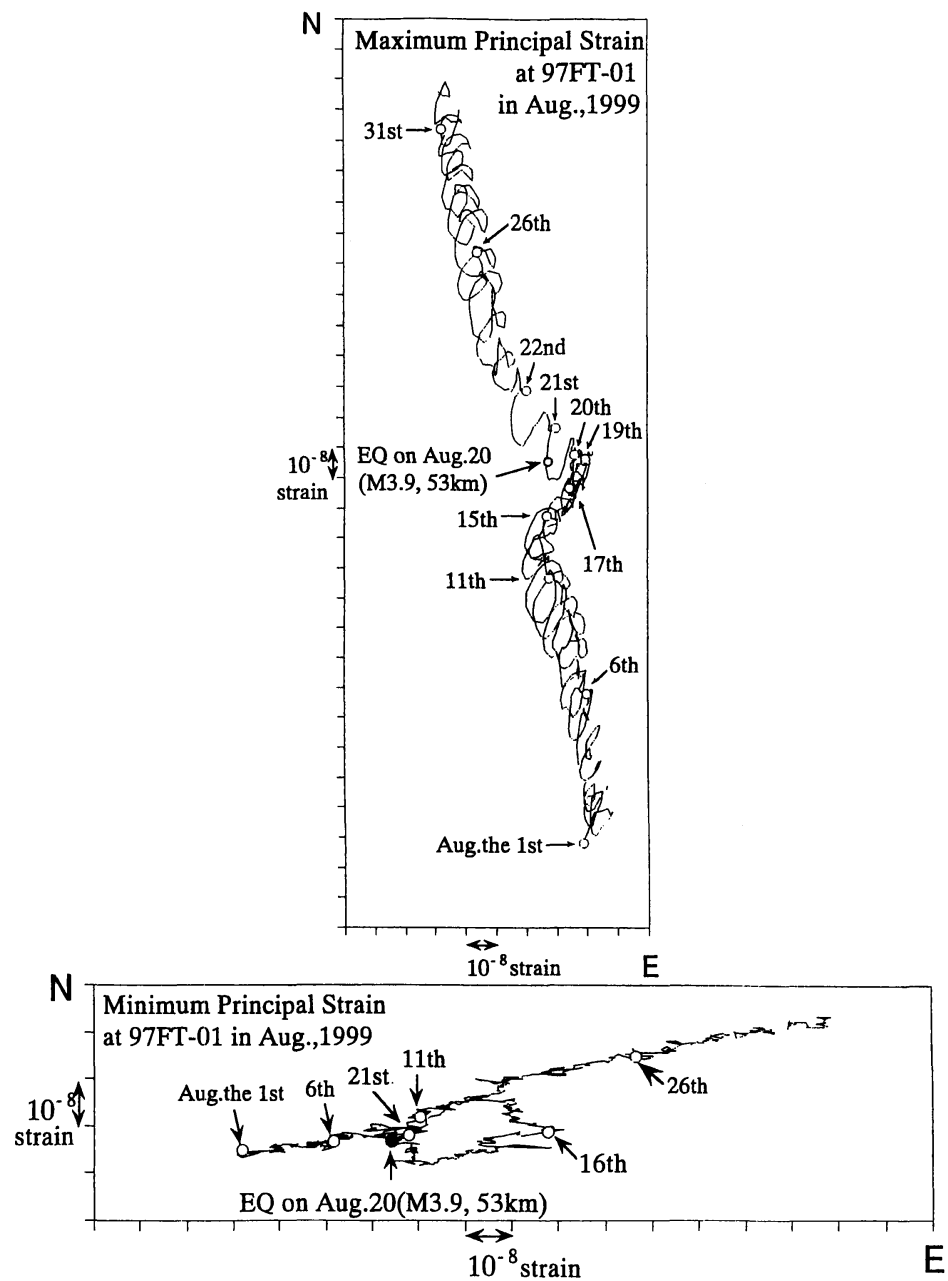

Fig. 9b 


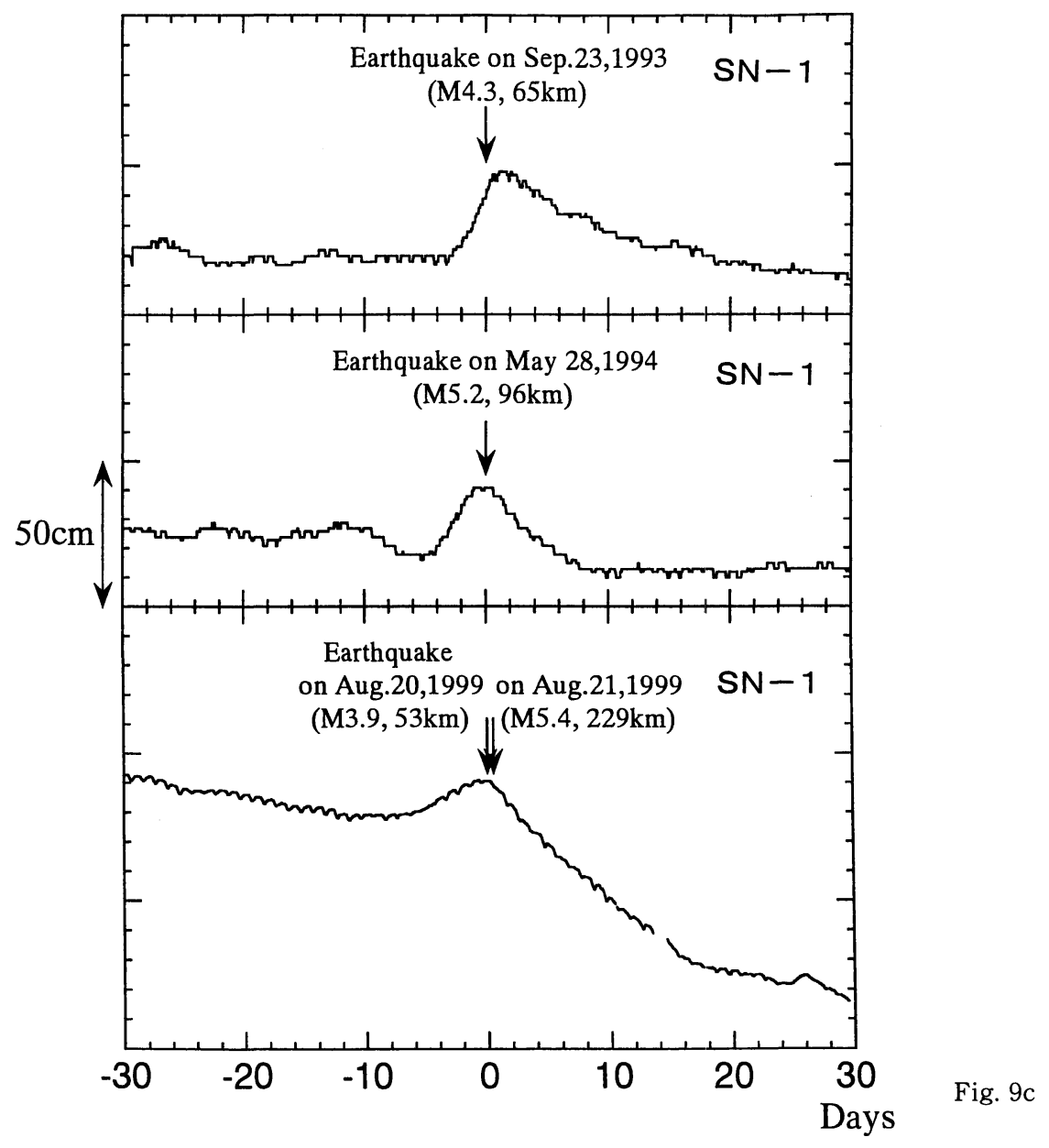

Fig. 9 a. Groundwater levels observed at SN-1 and 97FT-01 boreholes, and shear and areal strains calculated by the use of records obtained from strainmeters of multi-component borehole instrument in $160 \mathrm{~m}$ depth borehole at 97FT-01 station in the period from July 1 to Sep. 30, 1999 [JNC (2000)]. b. Loci of maximum and minimum principal strains obtained from strainmeters of multi-component borehole instrument in $160 \mathrm{~m}$ depth borehole at 97FT-01 station nearby the Tono Mine in August, 1999 [JNC (2000)]. c. Groundwater levels observed at SN-1 borehole nearby the Tono Mine in Central Japan, in the period from 30 days before and to 30 days after three earthquakes [JNC (2000)].

検出可能である」ことと「地震発生に関連した地殼变動 には面積歪や体積歪には現れないが 3 成分歪に現れる 変動が観測され，地震の前兆変化を観測する場合には体 積歪のみの観測では不十分であり, 多成分歪観測に変更 すべきである」ということが指摘できる.

地款活動総合観測装置は, 年が経つにつれて設置場所 が多くなり，徐々に設置深度が深くなってきた．現時点 では, $1000 \mathrm{~m}$ を超える深度に観測装置を設置できる. 地下深部の $S / N$ 比のよい観測地点が多くなれば, 本報 告で述べたような前兆的地款変動の観測事例が増え, 地 震発生のメカニズムの解析に貢献するはずである.
現時点では, 1 本の同軸ケーブルで, 地款活動総合観 測装置に必要な電源の供給とデジタルデータの双方向通 信を行うことができる. 多芯の複合ケーブルを省略でき たことから地下深部であっても観測装置の設置がしやす くなった. 将来は, 双方向通信の機能を使用し, 必要に 応じて観測装置内部の観測用プログラムを入れ替えられ るようにしたい.

ボアホールを掘削するためには膨大な経費が必要であ る. 同じボアホール観測孔に複数の観測装置を設置し, 鉛直方向のアレイ観測ができれば掘削したボーリング孔 を有効に利用できる. 近い将来, 同一のボアホールで設 
置深度を変えて複数の観測装置を設置し，アレイ観測が できる観測システムに発展させたい。

一方, 地殼に作用している応力状態をモニターする目 的で, 電池で作動する初期応力測定用のインテリジェン ト型丕計を開発してきた。この歪計は外部に信号線や電 源線がないため, 地下深部であってもオーバーコアリン グが行える.この測定装置であれば,

1) 解放歪のインバージョンから初期応力を求めるこ とができる。

2) 非破壊測定であり，同じ地点に地殼活動総合観測 装置を設置でき, 歪変化を介し応力状態をモニターでき る.

筆者らは, 初期応力の測定を行った同じ地点に地殻活 動総合観測装置を設置し, 丕変化を介する応力状態のモ ニターを開始した. 今後は, 応力の絶対変化の推移と周 辺地域の地款活動との関連を調查していきたい. 原位置 における応力値の測定とその絶対変化は, 地震予知研究 だけでなく, 空洞を利用する地下施設の施工, トンネル の掘削現場などにとって屯重要な技術である，現場の使 用条件に適合した歪計システムを開発し, 他の分野にお いても貢献したい.

\section{謝 辞}

岡田義光氏之匿名の査読者および編集委員の鷗谷 威 氏には数々の不備な点を指摘して頂き, 本文を改善する うえでたいへん有益であった，記して感謝致します．ま た, 多くの方々の協力によりこの開発研究を進めること ができた. 初期応力測定に関することでは, 北海道大学 大学院理学研究科の池田隆司教授 (独立行政法人防災科 学技術研究所在職中）に協力して頂いた. ボーリングの 工事に関する技術開発では住鉱コンサルタント株式会社 に, 测定装置のメカニカルな開発やセンシングの技術開 発に関することでは(有)テクノ菅谷, 株式会社マコメ研 究所, (有) システム技電, アジア通信工業株式会社, お よび(有)中日電工に協力して頂いた，関係した方々にお 礼を申し上げる.

\section{参考文献}

浅井康広 - 石井 紘 - 青木治三 - 大久保慎人 - 山内常 生, 2003 , 東濃におけるボアホールと横坑による 3 次 元多成分アレイ観測および能動実験による地壳変動・ 地下水研究と間隙弾性論への適用, 地壳変動, 地球ダ イナミクスの観測とモデル計算の最近の成果, 今後の 課題, 京都大学防災研究所 研究集会 (一般) $14 \mathrm{~K}-07$, 124-131.

池田隆司 - 小村健太郎 - 飯尾能久 - 石井 紘 - 小林洋二 ・ 西上欽也・山内常生, 2001 , 南海卜ラフ地震に向けた陸
域での地殼応力・丕測定, 地学雑誌, 110, 544-556. 石井 紘, 中尾 茂, 松本滋夫, 平田安廣, 1998, ボア ホール地殻活動総合観測装置で観測された伊豆半島東 方沖群発地震の前兆的地款変動, 地下深部における地 殻変動連続観測に向けて研究会集録, 東京大学地震研 究所 特定共同研究 (B), 4751 .

石井 紘・山内常生・松本滋夫, 2001a，最新の地震・ 地殻変動計測システムによる地震前兆現象の検出, 月 刊地球/号外 33, 188-196.

Ishii, H., T. Yamauchi, S. Matsumoto, Y. Hirata and S. Nakao, 2001b, Development of multi-component borehole instrument for earthquake prediction study, some observed example of precursory and co-seismic phenomena relating to earthquake swarms and application of the instrument for rock mechanics, in "Seismogenic Process Monitoring", ed H. Ogasawara, T. Yanagidani and M. Ando, BALKEMA, 365-377.

核燃料サイクル開発機構, 2000, 陸域地下構造フロン ティア研究, 平成 12 年度研究開発課題評価（中間評 価）報告書, 評価課題「陸域構造フロンティア研究」, (http: / / www. jnc. go. jp / siryou / hyouka / HY 000823).

King, C., S. Azuma, M. Ohno, Y. Asai., H. Peiming, G. Igarashi and H. Wakita, 2000, In search of earthquake precursors in the water-level data of 16 closely clustered wells at Tono, Japan, Geophys. J. Int., 143, 469-477.

松本滋夫・石井 紘・山内常生・窪田 亮, 2000, 超深 度ボーリング孔における初期応力測定のためのオー バーコアリングシステムの開発, 東京大学地震研究所 技術報告, $6,1-9$.

松本滋夫・石井 紘・山内常生, 2001, 深部ボーリング 孔などを利用した初期応力測定の問題点とその原因の 検討および改良について, 東京大学地震研究所技術研 究報告, 7, 15-30.

Miyabe, M., 1955, Vertical earth movement in Nankai district, Bull. Geogr. Survey Inst., 4, 1-14.

Mukai, A., T. Yamauchi, H. Ishii, S. Matsumoto, 2004, In situ stress measurement by the stress relief technique with a multi-component borehole instrument (submitted to EPS).

Okada, Y., E., Yamamoto and T., Ohkubo, 2000, Coswarm and preswarm crustal deformation in the east Izu Peninsula, central Japan, J. Geophys. Res., 105, 681-692.

山内常生・山田 守・奥田 隆, 1981, 降雨に対する地壳 歪レスポンスの異常と地震発生, 地震 2, 34, 301-310.

山内常生, 1981, 降雨に対する地殼歪レスポンスのシ ミュレーション, 測地学会誌, 27, 40-49.

Yamauchi, T., 1993, A Simulation of Broad-band Strain Response to Rainfall, Proceedings of CRCM '93, Kobe, December 6-11, 31-35.

山内常生・石井 紘・松本滋夫, 2000 , 超深度ボアホー ルにおける初期応力測定のためのインテリジェント回 収型歪計の開発, 物理探査学会第 102 回学術講演論文 集, 104-108. 